\title{
PENERAPAN COOPRATIVE LEARNING TIPE MIND MAPPING UNTUK MENINGKATKAN HASIL BELAJAR SISWA PADA SUBTEMA KEBERSAMAAN DALAM KEBERAGAMAN
}

\author{
Sukmah Rahmatdani, M.Pd ${ }^{1}$ \\ Ayu Kartika Rini² \\ 1sukmadani17@yahoo.co.id \\ 1 Dosen STKIP Subang \\ 2Mahasiswa PGSD FKIP Unpas
}

\begin{abstract}
This study aims to improve student learning outcomes by using model Cooperative Learning type Mind Mapping on the theme of togetherness togetherness subtema in Diversity. This research was conducted in the class IV D SDN Komplek Karang Taruna Sari and background of the students who showed less result of study which still low and many criteria of minimal mastery because teacher often use lecture motto which tend to monoton and not yet using model Cooperative Learning Type Mind Mapping which consist of 5 Phases of conveying goals and motivating students, presenting information, organizing students into study groups, guiding study and work groups, and evaluating. Assessment used in this research is Pretest and Posttest test technique to know student learning result of cognitive assessment, attitude assessment, making mind mapping and observation sheet to know teacher and student attitudes during learning process. The results showed an increase in the average of the assessment of learning outcomes. On the cognitive assessment of the average value of cycle $I$ is 69 while the second cycle reached 72.5 and the third cycle reached 74 , on the affective assessment of the average value of cycle I is 61 while the second cycle reached 63 and the third cycle reached 74. This shows that the use of model Cooperative Learning Type Mind Mapping can improve student learning outcomes on the theme of togetherness kebersamaa subtema in the diversity of class IV D SDN Komplek Karang Taruna Sari. Thus, the use of Cooperative Learning type Mind Mapping model can be used as one of the learning models to be applied to thematic learning with other themes and subthemes.
\end{abstract}

Keywords: Cooperative Learning Type Mind Mapping, learning outcomes.

\section{ABSTRAK}

Penelitian ini bertujuan untuk meningkatkan hasil belajar siswa dengan menggunakan model Cooperative Learning tipe Mind Mapping pada tema indahnya kebersamaan subtema kebersamaan dalam Keberagaman. 
Penelitian ini dilaksanakan dikelas IV D SDN Komplek Karang Taruna Sari dan dilatar belakangi keadaan siswa yang kurang menunjukkan hasil belajar yang masih rendah dan banyak kriteria ketuntasan minimal karena guru sering menggunakan motode ceramah yang cenderung monoton dan belum menggunakan model Cooperative Learning Tipe Mind Mapping yaitu terdiri 5 fase yaitu menyampaikan tujuan dan memotivasi siswa, menyajikan informasi, mengorganisasi siswa ke dalam kelompok-kelompok belajar, membimbing kelompok belajar dan bekerja, dan evaluasi. Penilaian yang digunakan pada penelitian ini adalah teknik tes Pretest dan postest untuk mengetahui hasil belajar siswa penilaian kognitif, penilaian sikap, penilaian membuat mind mapping dan lembar observasi untuk mengetahui kegaiatan guru dan siswa selama proses pembelajaran. Hasil penelitian menunjukkan adanya peningkatan rata-rata dari penilaian hasil belajar. Pada penilaian kognitif nilai rata-rata siklus I yaitu 69 sedangkan siklus II mencapai 72,5 dan siklus III mencapai 74 , pada penilaian afektif nilai rata-rata siklus I yaitu 61 sedangkan siklus II mencapai 63 dan siklus III mencapai 74 . Hal ini menunjukkan bahwa penggunaan model Cooperative Learning Tipe Mind Mapping dapat meningkatkan hasil belajar siswa pada tema indahnya kebersamaan subtema kebersamaa dalam keberagaman kelas IV D SDN Komplek Karang Taruna Sari. Dengan demikian, penggunaan model Cooperative Learning tipe Mind Mapping dapat dijadikan salah satu model pembelajaran untuk diterapkan pada pembelajaran tematik dengan tema dan subtema yang lainnya.

Kata kunci: Cooperative Learning Tipe Mind Mapping, hasil belajar.

\section{A. PEndahuluan}

Pendidikan sebagai sektor
yang paling penting dalam
meningkatkan kualitas hidup
manusia. Pendidikan juga
dipandang sebagai salah satu
aspek yang memiliki peranan
penting untuk membentuk manusia
yang berkualitas. Dengan demikian
pendidikan dipandang akan dapat
menghasilkan manusia yang
berkualitas, kompetitif juga mampu

bersaing di masa yang akan datang.

Hal ini yang berupa kegiatan menulis merupakan kegiatan yang diharapkan dapat meningkatkan motivasi untuk berkreasi dalam berbagai hal, yang dimulai dari mengeluarkan isi pikiran berupa ide atau gagasan. Dengan ide atau gagasan tersebut sumber daya manusia dapat terbentuk melalui pembelajaran, agar menjadi 
masyarakat yang produktif, aktif, kreatif dimasa yang akan datang.

$$
\text { Tujuan }
$$

pendidikan

mengarahkan pada pembentukan manusia Indonesia seutuhnya. Hal ini dijelaskan dalam UndangUndang Republik Indonesia Nomer 20 Tahun 2003 Pasal 1 Ayat 20 tentang Sistem Pendidikan Nasional menyebutkan sebagai berikut :

Pendidikan berfungsi
mengembangkan kemampuan-
kemampuan dan membentuk
watak serta peradaban bangsa,
bertujuan untuk
mengembangkan potensi
peserta didik agar menjadi
manusia yang beriman dan
bertakwa kepada Tuhan Yang
Maha Esa, berakhlak mulia,
sehat, berilmu, cakap, kreatif,
mandiri, dan menjadi warga
Negara yang demokratis serta
bertanggung jawab.
Komalasari

(dalam

Pembelajaran Kontekstual, 2013, hlm. 3) menyatakan pembelajaran merupakan suatu sistem atau proses membelajarkan pembelajar yang direncanakan, dilaksanakan dan dievaluasi secara sistematis agar pembelajar dapat mencapai tujuan-tujuan pembelajaran secara efektif dan efesien.
Sanjaya (dalam buku Huda, 2014, hlm. 13) mengungkapkan pembelajaran merupakan suatu sistem yang kompleks yang keberhasilannya dapat dilihat dari dua aspek yaitu aspek produk dan aspek proses. Keberhasilan pembelajaran dilihat dari sisi produk adalah keberhasilan siswa mengenai hasil yang diperoleh dengan mengabaikan proses pembelajaran.

Slavin (dalam buku Cooperative Learning, 2015, hlm. 4) mngungkapkan pengertian belajar merupakan proses perolehan kemampuan yang berasal dari pengalaman. Sedangkan menurut Gagne pengertian belajarmerupakan sebuah sistem yang didalamnya terdapat berbagai unsur yang saling terkait sehingga menghasilkan perubahan perilaku.

Trianto (dalam buku Mendesain Model Pembelajaran inovatif-progresif, 2009, hlm. 15) mengemukakan proses belajar terjadi melalui banyak cara baik disengaja maupun tidak disengaja dan berlangsung sepanjang waktu 
dan menuju pada suatu perubahan pada diri pembelajar.

Terdapat masalah yang dialami oleh siswa dalam kegiatan pembelajaran dan tidak muncul begitu saja, tetapi ada faktor-faktor penyebabnya. Apabila guru mampu mengidentifikasi penyebab timbulnya masalah yang dialami oleh siswa, maka guru tersebut akan dapat melakukan penanganan-penanganan yang tepat dalam memecahkan masalah pembelajarannya. Contoh masalah yang muncul dalam subtema keragaman budaya bangsaku yaitu siswa kurang memahami penjelasan guru, siswa kurang memahami konsep dasar materi, siswa kurang bisa mengkonsepkan materi, sikap siswa dalam kehidupa sehari-hari tidak nampak sudah mencapai indikator keberhasilan baik dalam aspek sikap, pengetahuan dan keterampilan.

Sesuai dengan setandar keberhasilan yang ada dalam kurikulum 2013 berupa indikator keberhasilan bahwa dalam keberhasilan pencapayan indikator siswa haruslah mampu mencapai keberhasilan mencapai KKM diman KKM sekolah adalah 75 dengan rentan nilai $A$ (Sangat Baik) berupa $92<A 100$, nilai $B$ (Baik) berupa $83<$ B 92 , nilai C (Cukup) berupa 75 C 83 , nilai D (Perlu Bimbingan) berupa $\mathrm{D}<75$ dalam buku Revisi Panduan Penilaian Untuk Sekolah Dasar (2016, hlm. 47).

Menurut hasil observasi pada kelas yang akan diteliti berdasarkan penjelasan wali kelas terdapat data besarnya nilai pencapayan siswa saat ini sebagai berikut :

1. Penilaian sikap peduli terdapat (55\%) dari 30 orang siswa di kelas IV C yang mencapai indikator sikap peduli.

2. Penilaian sikap santun terdapat (65\%) dari 30 orang siswa di kelas IV C yang mencapai indikator sikap santun.

3. Penilaian keterampilan berkomunikasi terdapat (50\%) dari 30 orang siswa di kelas IV C yang mencapai indikator keterampilan berkomunikasi.

Berdasarkan hasil renungan yang penulis lakukan maka penulis menyadari bahwa kesalahan berada pada guru bukan pada 
siswa, antara lain pembelajaran berpusat pada guru, keterlibatan siswa dalam pembelajaran kurang ada kesempatan untuk terlibat langsung dalam pembelajaran yang mengakibatkan siswa pasif. Berlatar belakang dari permasalahan tersebut, maka perlu melakukan Penelitian Tindakan Kelas (PTK), sebab menurut Suharsimi (2007, hlm. 3) berkesimpulan bahwa penelitian tindakan kelas adalah suatu perencanaan terhadap kegiatan belajar berupa sebuah tidakan, yang sengaja dimunculkan dan terjadi dalam sebuah kelas secara bersamaan. Tindakan tersebut diberikan oleh guru atau dengan arahan dari guru yang dilakukan oleh siswa.

$\begin{array}{ccc}\text { Solusi } & \text { alternatif } & \text { yang } \\ \text { digunakan } & \text { peneliti } & \text { untuk }\end{array}$
menyelesaikan permasalahan yang timbul dalam pembelajaran tematik yaitu dengan menggunakan model pembelajaran Cooperatif tipe Mind Mapping dalam sintak kegiatan dalam RPP.

Tony Buzan dalam bukunya “Buku Pintar Mind Mapp”, Metode
Mind Mapping adalah suatu cara mencatat yang kreatif, efektif dan secara harfiah akan memetakan pikiran-pikiran (Tony Buzan, 2009, hlm. 4).

Johnson dan Johnson (dalam Huda, 2014, hlm. 31) mengemukakan bahwa pembelajaran cooperative berarti working together to accomplish shared goals (bekerja sama untuk mencapai tujuan bersama), setiap anggota sama-sama berusaha mencapai hasil yang nantinya bias di rasakan oleh semua anggota kelompok.

\section{Caroline}

Edward mengatakan, metode Mind Mapping adalah cara paling efektif dan efisien untuk memasukan, menyimpan dan mengeluarkan data dari atau ke otak. Sistem ini bekerja sesuai cara kerja alami otak kita, sehingga dapat mengoptimalkan seluruh potensi dan kapasitas otak manusia (Caroline Edward, 2009, hlm. 64).

$$
\text { Sejujurnya dalam }
$$
penggunaan model pembelajaran untuk pembelajaran Tematik di SD jarang bahkan hampir tidak pernah 
digunakan oleh guru-guru SD, padahal model pembelajaran itu ada dan dapat di gunakan dalam kegiatan pembelajaran. Oleh karena itu tugas yang saya laksanakan ini mencoba melakukan penelitian dengan judul "Penerapan Metode Cooprative Learning Tipe Mind Mapping Untuk Meningkatkan Hasil Belajar Siswa Pada Subtema Keragaman Budaya Bangsaku".

Adapun hasil penelitian yang mendukung tentang keberhasilan metode Cooprative Learning tipe Mind Mapping yaitu hasil penelitianan Febririvandi, 2010 yang berjudul "Impelementasi Teknik Mind Mapping untuk Meningkatkan Daya Ingat Dalam Pembelajaran Lingkungan Pelajaran IPS Kelas III SD Negri 42 Tanjung Pandan".

Adapun keunggulan dari Cooperative Learning sebagai berikut :

1. Melalui Cooperative Learning siswa tidak terlalu menggantungkan pada guru, akan tetapi dapat menambah kepercayaan kemampuan berfikir sendiri, menemukan informasi dari berbagai sumber, dan belajar dari siswa yang lain.

2. Cooperative Learning dapat mengembangkan kemampuan mengungkapkan ide atau gagasan dengan kata-kata secara verbal dan membandingkannya dengan ide-ide orang lain.

3. Cooperative Learning dapat membantu anak untuk respek pada orang lain dan menyadari akan segala keterbatasannya serta menerima segala perbedaan.

4. Interaksi selama pembelajaran Cooperative berlangsung dapat meningkatkan motivasi dan memberikan rangsangan untuk berfikir, hal ini berguna untuk proses pendidikan jangka panjang.

5. Cooperative Learning dapat membantu memberdayakan setiap siswa untuk lebih bertanggung jawab dalam belajar

6. Cooperative Learning merupakan suatu strategi yang 


$\begin{array}{lr}\text { cukup ampuh } & \text { untuk } \\ \text { meningkatkan } & \text { prestasi } \\ \text { akademik skaligus kemampuan } & \text { termasuk } \\ \text { sosial, } & \text { hubungan } \\ \text { mengembangkan } & \text { positif } \\ \text { interpersonal yang } & \text { lain, } \\ \text { dengan yang } & \end{array}$

mengembangkan keterampilan me-manage waktu.

7. Melalui Cooperative Learning dapat mengembangkan kemampuan siswa untuk menguji ide dan menerima umpan balik. Siswa dapat berpraktik memecahkan masalah tanpa takut membuat kesalahan, karena keputusan yang di buat adalah tanggung jawab kelompoknya.

8. Cooperative Learning dapat meningkatkan kemampuan siswa menggunakan informasi dan kemampuan belajar abstrak menjadi nyata.

Tentu saja pembelajaran yang baik harus ditunjang oleh metode yang sesuai dengan materi pelajaran,Sebagai dasar teori yang saya gunakan yang merupakan medel pembelajaran Cooprative sebagai metode yang dapat digunakan dalam kegiatan dimana siswa dapat berperan aktif dalam setiap kegiatan yang juga menyenangkan bagi mereka, adanya beberapa tahapan dalam metetode Coopratve dengan tipe Mind Mapping sebagai tahapan dalam setiap kegiatan yang dibantu juga oleh media pembelajaran agar dapat membantu setiap siswa agar dapat lebih memahami dalam setiap kegiatannya tanpa melupakan peran penting guru yang membimbing mengawasi dan membiasakan setiap kegiatan yang lakukan siswa dalam kegiatan belajar mengajar dalam kelas.

\section{B. LANDASAN TEORI}

1. Model Cooperative Learning Tipe Mind Mapping

\section{a. Definisi Cooperative}

\section{Learning Tipe Mind Mapping}

Penelitian ini mengambil model Cooperative Learning tipe Mind Mapping sebagai model yang akan di gunakan dalam penelitian dengan banyak teori tentang model ini peneliti mengambil teori yang di kemukakan oleh Piaget, Vigotsky, Tony Buzan, Johnson dan Johnson, Caroline Edward, 
Wolkfolk, Slavin, Parker, dan Stahl sebagai dasar teori model Cooperative Learning yang menjadi model untuk penelitian ini.

Model pembelajaran koopertif ini dikembangkan dari teori belajar konstruktivisme yang dilahirkan oleh seorang ilmuwan pendidikan bernama Piaget di mana dalam teori perkembangan Piaget (dalam Slavin, 2015, hlm. 145) mengatakan bahwa teori konstruktivisme, yang memandang perkembangan kognitif sebagai suatu proses di mana anak secara aktif membangun sistem makna dan pemahaman realitas melalui pengalaman-pengalaman dan interaksi-interaksi mereka.

Teori perkembangan kognitif yang di kembangkan oleh Piaget tersebut lalu di kembangkan kembali oleh muridnya yaitu Vigotsky menjadi teori pembelajaran sosial yang berdasarkan teori konstruktivisme.

Teori perkembangan Piaget lalu di kembangkan oleh Vigotsky (dalam Huda, 2014, hlm. 21) mengemukakan bahwa perkembangan tergantung baik pada faktor biologis menentukan fungsi-fungsi elementer memori, atensi, persepsi, dan stimulusrespon, faktor sosial sangat penting artinya bagi perkembangan fungsi mental lebih tinggi untuk pengembangan konsep, penalaran logis, dan pengambilan keputusan.

Teori model Mind Mapping pun di ungkapkan oleh Tony Buzan metode Mind Mapping adalah suatu cara mencatat yang kreatif, efektif dan secara harfiah akan memetakan pikiran-pikiran (Tony Buzan, 2009, hlm. 4).

Model

Cooperative dikembangkan oleh Johnson dan Johnson (dalam Huda, 2014, hlm. 31) mengemukakan bahwa pembelajaran Cooperative berarti working together to accomplish shared goals (bekerja sama untuk mencapai tujuan bersama), setiap anggota sama-sama berusaha mencapai hasil yang nantinya bisa di rasakan oleh semua anggota kelompok.

Model Mind Mapping pun di ungkapkan oleh Caroline Edward (2009, hlm. 64) mengatakan "Metode Mind Mapping adalah cara 
paling efektif dan efisien untuk memasukan, menyimpan dan mengeluarkan data dari atau ke otak. Sistem ini bekerja sesuai cara kerja alami otak kita, sehingga dapat mengoptimalkan seluruh potensi dan kapasitas otak manusia".

Perkembangan kooperatif pun di cetuskan oleh Wolkfolk yang mendefenisikan (dalam Warsono dan Hariyanto, 2013) "Pembelajaran kooperatif adalah suatu pengaturan yang memungkinkan para mahasiswa bekerja sama dan belajar bersama dan saling membantu secara interaktif utuk mencapai tujuan pembelajaran".

Adapun metode Cooperative yang di ungkapkan oleh Slavin (dalam Isjoni, 2011, hlm.17) menjelaskan tentang pembelajaran Cooperative sebagai berikut :

Pembelajaran kooperatif adalah solusi ideal terhadap masalah menyediakan kesempatan berinteraksi secara kooperatif dan tidak dangkal kepada kepada para siswa dari latar belakang ras atau etnik yang berbeda. Metode-metode pembelajaran kooperatif secara khusus menggunakan kekuatan dari sekolah yang menghapuskan perbedaan kehadiran para siswa dari latar belakang rasatau etnik yang berbeda untuk meningkatkan hubungan antara kelompok. Dalam metode-metode ini, kerjasama diantara para siswa ditekankan melalui penghargaan dan tugas-tugas di dalam kelas dan juga penghargaan oleh guru, yang mencoba mengkomunikasikan sikap 'semua untuk satu, satu untuk semua.

Teori Cooperative juga di ungkapkan oleh Parker (dalam Huda, 2014, hlm. 29) mendefinisikan kelompok kecil Cooperative sebagai suasana pembelajaran dimana para siswa salaing berinteraksi dalam kelompok-kelompok kecil untuk mengerjakan tugas akademik demi mencapai tujuan bersama.

Adapun

Stahl mengungkapkan tentang teori Cooperative Learning (dalam Isjoni, 2011, hlm. 24) yang mengemukakan bahwa melalui model Cooperative Learning siswa dapat memperoleh pengetahuan, kecakapan sebagai pertimbangan 
untuk berfikir dan menentukan serta berbuat dan berpatisipasi sosial.

Berdasarkan penjelasan
tersebut maka peneliti
menyimpulkan bahwa dengan
model Cooperative Lerning dapat
meningkatkan hasil belajar siswa
dengan kegiatan pembelajaran
secara berkelompok dan dengan
menggunakan tipe Mind Mapping
dapat membantu siswa dalam
mengkonsep pikiran bersama
kelompoknya bersama-sama
menjadi sebuah peta pikiran
kelompoknya.

\section{b. Karakteristik Cooperative} Learning Tipe Mind Mapping Model Cooperative Learning tipe Mind Mapping sendiri memiliki karakteristik tersendiri adapun teori-teori yang memuat karakteristik pada Cooperative Learning tipe Mind Mapping yang di ambil peneliti berdasrkan teori yang di kemukakan oleh Slavin dan Huda.

Teori karakteristik Cooperative yang di ungkapkan oleh Slavin (dalam buku Isjoni, 2011, hlm. 21) menyebutkan tiga karakteristik

pembelajaran Cooperative Learning yaitu sebagai berikut :

1) Penghargaan kelompok.

2) Pertanggungjawaban individu.

3) Kesempatan yang sama untuk berhasil.

Adapun

Huda

mengemukakan karakteristik model Cooperative Learning tersebut sebagai berikut :

1) Interpedensi positif.

2) Interaksi promotif.

3) Akunbilitas individu.

4) Keterampilan interpersonal dan kelompok kecil.

5) Pemrosesan kelompok.

Berdasarkan penjelasan tersebut maka peneliti menyimpulkan bahwa karakteristik model Cooperative Learning ini sangat memerlukan adanya tanggung jawab dari setiap anggota karna itu walau bersifat berkelompok namun peran setiap anggota sangat penting dalam keberhasilan kelompok.

c. Kelebihan Cooperative Learning Tipe Mind Mapping Model Cooperative Learning ini memiliki kelebihan dalam 
kegiatan pembelajaran karna itu model ini di gunakan peneliti dalam penelitian, peneliti mennguanakan pendapat Jarolimek \& Parker dan Johnson, dkk sebagai pengemuka kelebihan yang dimiliki model Cooperative Learning.

Jarolimek \& Parker (dalam buku Isjoni, 2011, hlm. 24) mengemukakan kelebihan yang ada dalam model Cooperative Learning sebagai berikut :

1) Saling ketergantungan yang positif.

2) Adanya pengakuan dalam merespon perbedaan individu.

3) Siswa dilibatkan dalam perencanaan dan pengolahan kelas.

4) Suasana kelas yang rileks dan menyenangkan.

5) Terjalin hubungan yang hangat dan bersahabat antar siswa dengan guru.

6) Memiliki banyak kesempatan untuk meng-ekspresikan pengalaman emosi yang menyenangkan.

Teori model Cooperative juga di kemukakan oleh Johnson, dkk (dalam buku Huda, 2014, hlm. 66) setelah dilakukan tiga kali percobaan terdapat kelebihan dari model Cooperative Learning sebagai berikut :

1) Hasil pembelajaran yang lebih tinggi.

2) Relasi antar siswa lebih positif.

3) Kesehatan psikologis yang lebih baik.

Berdasarkan penjelasan tersebut maka peneliti menyimpulkan bahwa kelebiahan model Cooperative Learning dalam kegiatan pembelajaran baigi siswa menimbulkan peningkatan dari beberapa aspek baik hasil pembelajaran maupun psikologis siswa tersebut.

\section{d. Kekurangan Cooperative}

\section{Learning Tipe Mind Mapping}

Adapun kekurangan yang dimiliki oleh model Cooperative Learning yang di kemukakan oleh Jarolimek \& Parker dan Johnson, dkk.

Bahwa Jarolimek \& Parker (dalam buku Isjoni, 2011, hlm. 24) mengemukakan kekurangan yang ada dalam model Cooperative Learning sebagai berikut :

1) Guru harus mempersiapkan 
pembelajaran secara matang dan waktu.

2) Agar proses pembelajaran dapat berjalan lancer maka dibutuhkan dukungan fasilitas, alat dan biaya yang cukup memadai.

3) Selama kegiatan diskusi kelompok berlangsung, ada kecenderungan topic permasalahan yang sedang dibahas meluas sehingga banyak yang tidak sesuai dengan waktu yang telah ditentukan.

4) Saat diskusi, terkadang didominasi oleh seseorang, hal ini mengakibatkan siswa yang lain menjadi pasif.

Adapun Johnson, dkk (dalam buku Huda, 2014, hlm. 68) mengemukakan bahwa setelah dilakukan tiga kali percobaan terdapat kelebihan dari model Cooperative Learning sebagai berikut :

1) Penilaian yang diberikan didasarkan kepada hasil kerja kelompok. Namun demikian, guru perlu menyadari, bahwa sebenarnya hasil atau prestasi yang diharapkan adalah prestasi setiap individu siswa.

2) Keberhasilan model pembelajaran kooperatif dalam upaya mengembangkan kesadaran berkelompok memerlukan periode waktu yang cukup panjang.

3) Walaupun kemampuan bekerjasama merupakan kemampuan yang sangat penting untuk siswa, akan tetapi banyak aktivitas dalam kehidupan yang hanya didasarkan kepada kemampuan secara individual.

4) Oleh karena itu idealnya melalui model pembelajaran kooperatif selain siswa belajar bekerja sama, siswa juga harus belajar bagaimana membangun kepercayaan diri.

Berdasarkan penjelasan tersebut maka peneliti menyimpulkan bahwa kekurangan model Cooperative Learning dalam kegiatan pembelajaran baigi siswa membutuhkan usaha siswa dalam kegiatannya dan guru sebagai perangsang siswa agar aktif dan merasa percaya diri dalam 
mengungkapkan pendapatnya pada anggota kelompoknya.

\section{e. Langkah - Langkah \\ Cooperative Learning Tipe \\ Mind Mapping}

Model Cooperative Learning memiliki langkah-langkah tersendiri dalam kegiatannya seperti yang di ungkapkan oleh Abdulhak (dalam buku Isjoni, 2011, hlm. 85) menyebutkan langkah-langkah dalam model Cooperative Learning sebagai berikut :

1) Merumuskan secara jelas apa yang harus dicapai pesera belajar.

2) Memilih bentuk kegiatan pembelajaran yang paling tepat.

3) Menjelaskan secara detail proses pembelajaran Cooperative.

4) Memberikan tugas yang paling tepat dalam pembelajaran.

5) Menyiapkan bahan belajar yang memudahkan peserta belajar dengan baik.

6) Melaksanakan pengelompokan peserta belajar.

7) Mengembangkan system pujian untuk kelompok atau perorang pesera belajar.

8) Memberikan bimbingan yang cukup kepada peserta belajar.

9) Menyiapkan instrument penilaian yang tepat.

10) Mengembangkan system pengarsipan data kemajuan peserta belajar.

11) Melaksanakan refleksi.

Adapun langkah-langkah Cooperative Learning yang di ungkapkan Huda dalam bukunya “Cooperative Learning” (2014, hlm. 163) mengemukakan langkahlangkah kegiatan pembelajaran Cooperative sebagai berikut :

1) Memilih metode, teknik, dan struktur pembelajaran Cooperative.

2) Menata ruang kelas, untuk pembelajaran Cooperative.

3) Merangking siswa.

4) Menetukan jumlah kelompok.

5) Membentuk kelompokkelompok.

6) Merancang "Team Bulding" untuk setiap kelompok.

7) Mempresentasikan materi pembelajaran.

8) Membagikan lembar kerja.

9) Menugaskan siswa 
mengerjakan kuis secara sintak-sintak dalam model mandiri.

pembelajaran Cooperative

10) Menilai dan menskor kuis Learning tipe Mind Mapping.

siswa.

11) Memberikan penghargaan

1) Menyampaikan tujuan dan pada kelompok.

12) Mengevaluasi prilaku-prilaku (anggota) kelompok.

Berdasarkan penjelasan tersebut maka peneliti menyimpulkan bahwa setiap langkah haruslah memperhitungkan isi meteri yang akan di pelajari dengan waktu yang dapat di gunakan dalam kegiatan serta pengaturan pembentukan kelompok haruslah di perhitungkan dengan baik agar setiap kelompok memiliki anggota yang dapat bekerja sama dengan baik agar kegiatan pembelajaran mencapai tujuan.

\section{f. Sintak Cooperative Learning} Tipe Mind Mapping

Cooperative Learning tipe Mind Mapping memiliki sitak dalam kegiatan pembelajaran karna dalam kegiatan pembelajaran memerlukan langkah-langkah yang diharapkan dapat mencapai tujuan pembelajaran, berikut adalah memotivasi siwa.

2) Menyajikan informasi.

3) Mengorganisasi siswa ke dalam kelopok-kelompok belajar.

4) Membimbing kelompok belajar dan bekerja.

5) Evaluasi.

6) Memberikan penghargaan.

\section{Hasil Belajar}

\section{a. Definisi Hasil Belajar}

Kegiatan belajar mengajar tidak akan terlepas dari adanya hasil yang didapatkan melalui kegiatan pembelajaran itu sendiri karna itu pentingnya hasil belajar sebagai bahan evaluasi dari kegiatan pembelajaran yang sudah dilakukan pengajar, dalam pengambilan hasil belajar terdapat beberapa aspek yang dapat dinilai sebagai aspek hasil belajar yang dapat di gunakan sebagai acuan evaluasi kegiatan dan mencakup unsur yang dapat melihat hasil 
belajar peserta didik dalam kegiatan.

Peneliti mengunakan teori hasil belajar yang dikemukakan oleh Nana Sudjana, Musfiqun, Muhibbin Syah, dan Buku Panduan Penilaian SD sebagai dasar teori hasil belajar yang digunakan dalam penelitian ini.

Teori hasil belajar yang di kemukakan Nana Sudjana (2013, hlm. 22) mengatakan bahwa "Hasil belajar adalah kemampuankemampuan yang dimiliki siswa setelah ia menerima pengalaman belajarnya".

Dalam sistem pendidikan di Indonesia, kategori hasil belajar yang digunakan adalah kategory Bloom, yang membagi penilaian kedalam tiga aspek yaitu kognitif, afektif dan psikomotor.

Adapun yang di kemukakan Nana Sudjana (2013, hlm. 23) menjelaskan ketiga aspek itu sebagai berikut:

1. Ranah kognitif.

2. Ranah Afektif.

3. Ranah Psikomotor.

Hasil belajar adalah sesuatu yang dicapai atau diperoleh siswa berkat adanya usaha atau pikiran yang mana hal tersebut dinyatakan dalam bentuk penugasan, pengetahuan, dan kecakapan dasar yang terdapat dalam berbagai aspek kehidupan sehingga Nampak pada diri individu penggunaan terhadap sikap, pengetahuan dan kecakapan dasar yang terdapat dalam berbagai aspek kehidupan sehingga nampak pada diri individu perubahan tingkah laku secara kuantitatif.

Hasil belajar pun di kemukakan Musfiqun (2012, hlm. 8) "Hasil belajar siswa dipengaruhi oleh dua faktor utama, yaitu faktor dari dalam diri siswa (Internal Factor) dan faktor dari luar atau lingkungan siswa (Eksternal Factor)".

Adapun menurut Muhibbin Syah (dalam buku Musfiqun, 2012, hlm. 11) membedakan factor-faktor yang mempengaruhi hasil belajar menjadi tiga macam, yaitu sebagai berikut :

1) Faktor internal, yaitu keadaan atua kondisi jasmani dan rohani peserta didik. 
2) Faktor eksternal, yaitu kondisi lingkungan sekitar peserta didik.

3) Faktor pendekatan belajar, yaitu jenis upaya belajar siswa yang meliputi strategi dan metode yang digunakan untuk melakukan

kegiatan pembelajaran.

Buku Panduan Penilaian SD (2016, hlm. 5) "Penilaian adalah proses pengumpulan dan pengolahan informasi untuk mengukur pencapaian hasil belajar peserta didik. Dalam melaksanakan penilaian, pendidik dan satuan pendidikan harus mengacu pada Standar Penilaian Pendidikan".

Dari beberapa pendapat para ahli, peneliti menyimpulkan bahwa ada beberapa faktor yang mempengaruhi hasil belajar yaitu faktor internal yang berasal dari dalam diri siswa dan faktor eksternal yang berasal dari lingkungan sekitarnya.

\section{b. Prinsip-Prinsip Hasil Belajar}

Hasil belajar memiliki prinsipprinsip sebagai acuan pengumpulan penilaian yang harus di perhatikan pengajar dalam hal ini sebagai bahan pertimbangan. Dalam melaksanakan penilaian hasil belajar, pendidik perlu memperhatikan prinsip-prinsip penilaian sebagai berikut:

1) Valid/Sahih

Penilaian hasil belajar oleh pendidik harus mengukur pencapaian kompetensi yang ditetapkan dalam standar isi (standar kompetensi dan kompetensi dasar) dan standar kompetensi lulusan. Penilaian valid berarti menilai apa yang seharusnya dinilai dengan menggunakan alat yang sesuai untuk mengukur kompetensi.

2) Objektif

Penilaian hasil belajar peserta didik hendaknya tidak dipengaruhi oleh subyektivitas penilai, perbedaan latar belakang agama, sosial-ekonomi, budaya, bahasa, gender, dan hubungan emosional.

3) Transparan atau Terbuka

Penilaian hasil belajar oleh pendidik bersifat terbuka artinya prosedur penilaian, kriteria penilaian dan dasar pengambilan keputusan terhadap hasil belajar 
peserta didik dapat diketahui oleh semua pihak yang berkepentingan. 4) Adil

Penilaian hasil belajar tidak menguntungkan atau merugikan peserta didik karena berkebutuhan khusus serta perbedaan latar belakang agama, suku, budaya, adat istiadat, status sosial ekonomi, dan gender.

5) Terpadu

Penilaian hasil belajar oleh pendidik merupakan salah satu komponen yang tak terpisahkan dari kegiatan pembelajaran.

6) Menyeluruh dan berkesinambungan

Penilaian hasil belajar oleh pendidik mencakup semua aspek kompetensi dengan menggunakan berbagai teknik penilaian yang sesuai, untuk memantau perkembangan kemampuan peserta didik.

7) Sistematis

Penilaian hasil belajar oleh pendidik dilakukan secara berencana dan bertahap dengan mengikuti langkah-langkah baku.

8) Akuntabel
Penilaian hasil belajar oleh pendidik dapat dipertanggungjawabkan, baik dari segi teknik, prosedur, maupun hasilnya.

9) Beracuan Kriteria

Penilaian hasil belajar oleh pendidik didasarkan pada ukuran pencapaian kompetensi yang ditetapkan.

http://makalahpendidikan-

sudirman.blogspot. co.id/2013/09/ prinsip-penilaian-hasil-belajar.html Adapun prinsip-prinsip penilaian menurut Piaget (dalam buku Rusman, 2012, hlm. 201) menjelaskan sebagai berikut:

1) Valid

Hasil belajar harus mengukur apa yang seharusnya diukur dengan menggunakan jenis tes yang terpercaya atau sahih.

2) Mendidik

Hasil belajar harus
memberikan sembangan positif pada pencapaian hasil belajar siswa.

3) Berorientasi Pada Kompetensi Hasil belajar harus menilai pencapaian kompetensi siswa meliputi seperangkat pengetahuan, 
sikap, ketrampilan, dan nilai yag terefleksikan dalam kebiasaan berfikir dan bertindak.

4) Adil dan Obyektif

Hasil belajar harus mempertimbangkan rasa keadilan dan obyektifitas siswa tanpa membeda-bedakan jenis kelamin, latar belakang budaya, dan berbagai kal yang memberikan konstribusi pada pembelajaran.

5) Terbuka

Hasil belajar hendaklah dilakukan secara terbuka bagi berbagai kalangan sehingga keputusan tentang keberhasilan siswa jelas bagi pihak-pihak yang berkepentingan, tanpa ada rekayasa atau sembunyi-sembunyi yang dapat merugikan semua pihak.

6) Berkesinambungan

Hasil belajar harus ditinjau secara berkesinambungan sehingga terlihat perkembangan yang terjadi pada siswa dalam setiap kegiatan pembelajaran.

7) Menyeluruh

Hasil belajar harus ditinjau secara menyeluruh sehingga terlihat perkembangan yang terjadi pada siswa dalam setiap kegiatan pembelajaran.

8) Bermakna

Hasil belajar diharapkan mempunyai makna yang siginifikan bagi semua pihak. Untuk itu, KBM hendaknya mudah dipahami dan dapat ditindak lanjuti oleh pihakpihak yang berkempetingan. http://budiman-komunity.blogspot. co.id/2016/11/karakteristik-hasilbelajar.html $? \mathrm{~m}=1$

\section{c. Karakteristik Hasil Belajar}

Psikologi Pendidikan oleh Surya (dalam Psikologi Belajar oleh Muhibbin Syah, 2003) disebut juga sebagai prinsip-prinsip hasil belajar. Diantara ciri-ciri perubahan khas yang menjadi karakteristik hasil balajar yang terpenting adalah :

1) Perubahan itu intensional

2) Perubahan itu positif dan aktif

3) Perubahan itu efektif dan fungsional

$$
\text { Syaiful Bahri Djamarah }
$$
(dalam buku Psikologi Belajar, 2008) mengemukakan karakteristik hasil belajar sebagai berikut :

1) Perubahan yang terjadi secara sadar. 
2) Perubahan dalam belajar bersifat fungsional.

3) Perubahan dalam belajar bersifat positif dan aktif.

4) Perubahan dalam belajar bukan bersifat sementara.

5) Perubahan dalam belajar bertujuan atau terarah.

6) Perubahan mencakup seluruh aspek tingkah laku.

Berdasarkan pendapat para ahli tentang karakteristik hasil belajar tersebut peneliti mengambil kesimpulan hasil belajar memiliki suatu acuan yang menggambarkan akan perubahan dalam setiap pembelajarannya karna itu dalam setiap hasil belajar haruslah terlihat peningkatan hasil belajar siswa dalam beberapa aspek yang ingin ditingkatkan.

\section{d. Unsur-Unsur Hasil Belajar}

Dalam sistem pendidikan di Indonesia, kategori hasil belajar yang digunakan adalah kategory Bloom, yang membagi penilaian kedalam tiga aspek yaitu kognitif, afektif dan psikomotor.

Unsur-unsur hasil belajar yang di kemukakan oleh Arikunto (2003, hlm. 117) mengemukakan bahwa ada 3 ranah atau domain besar, yang terletak pada tingakatan ke-2 yang selanjutnya disebut taksonomi yaitu: ranah kognitif (Cognitive Domain), ranah afektif (Affektive Domain), dan ranah psikomotor (Psycomotor Domain).

Adanya 3 aspek ranah yang di kemukakan oleh Nana Sudjana (2016, hlm. 22) menjelaskan ketiga aspek itu sebagai berikut :

1) Ranah kognitif

Berkenaan dengan hasil belajar intelektual yang terdiri dari enam aspek yakni pengetahuan atau ingatan, pemahaman aplikasi,analisis,sintesis dan evaluasi.Kedua aspek pertama disebut kogntif tingkat rendah dan empat aspek berikutnyadisebut kognitif tingkat tinggi.

2) Ranah Afektif

Berkenaan dengan sikap yang terdiri dari lima aspek yakni penerimaan, jawaban, atau reaksi, penilaian, organisasi, dan internalisasi.

3) Ranah Psikomotor

Berkenaan dengan hasil belajar dengan keterampilan dan 
kemampuan bertindak. Ada enam aspek ranah psikomotorik yakni gerakan repleks,keterampilan gerakan dasar, kemampuan konseptual, keharmonisan atau ketepatan, gerakan keterampilan kompleks, dan gerakan ekspresip dan interpretasi.

Menurut penjelasan tersebut peneliti menyimpulkan bahwa hasil belajar seluruh kecakapan yang mencakup ranah kognitif, afektif, dan psikomotorik yang diperoleh melalui proses belajar mengajar di sekolah dinyatakan dengan angka dan diukur dengan menggunakan tes hasil belajar dan pengamatan guru.

\section{METODE PENELITIAN}

Metode berasal dari Bahasa Yunani "Methodos" yang berarti cara atau jalan yang ditempuh. Sehubungan dengan upaya ilmiah, maka metode menyangkut masalah cara kerja untuk dapat memahami objek yang menjadi sasaran ilmu yang bersangkutan. Fungsi metode berarti sebagai alat untuk mencapai tujuan.

Penelitian tindakan kelas merupakan penelitian tindakan yang dilakukan dalam pembelajaran di kelas yang memiliki fungsi meningkatkan suatu pembelajaran sehingga tujuan pembelajaran dapat tercapai dengan maksial. Hal ini sesuai dengan definisi menurut para ahli di bawah ini sebagai berikut:

Sugiyono (2012, hlm. 2) metode penelitian merupakan cara ilmiah untuk mendapatkan data dengan tujuan dan kegunaan tertentu.

Kemmis dan Taggart (dalam Wibawa, 2014, hlm.02) mengemukakan bahwa penelitian tindakan adalah suatu bentuk penelitian reflektif diri kolektif yang dilakukan oleh pesertapesertanya dalam situasi sosial untuk meningkatkan penalaran dan keadilan praktik pendidikan dan praktik sosial mereka, serta pemahaman mereka terhadap praktik-praktik itu dan terhadap situasi tempat dilakukan praktikpraktik tersebut.

Wardani (2014, hlm.03) mengemukakan bahwa penelitian tindakan kelas merupakan satu penelitian pula, yang dengan 
sendirinya mempunyai berbagai aturan dan langkah yang harus diikuti. Penelitian tindakan kelas merupakan terjemahan dari Classroom Action Research, yaitu satu Action Research yang dilakukan di kelas.

Wardani (2014, hlm.04) mengemukakan bahwa ide pokok dari penelitian tindakan kelas adalah sebagai berikut:

1) Penelitian tindakan adalah satu bentuk inkuiri atau penyelidikan yang dilakukan melalui refleksi diri.

2) Penelitian tindakan dilakukan oleh peserta yang terlibat dalam situasi yang diteliti, seperti guru, siswa, atau kepala sekolah.

3) Penelitian tindakan dilakukan dalam situasi sosial, termasuk situasi pendidikan.

Adapun pengertian tentang PTK yang dikemukakan oleh Arikunto dalam Dadang Iskandar dan Narsim (2015, hlm.5) Penelitian Tindakan Kelas adalah penelitian tindakan yang dilakukan atas dasar persoalan pembelajaran yang mucul dikelas guna meningkatkan

proses

pembelajaran sehingga tujuan

pembelajaran dapat tercapai.

Sedangkan

menurut

Suhardjono dalam Dadang Iskandar dan Narsim (2015, hlm.5) PTK merupakan penelitian tindakan kelas yang dilakukan dengan tujuan memperbaiki mutu praktik pembelajaran di kelas. Hasil penelitian kemudian dibuat laporan sesuai dengan kondisi nyata yang dikaukan para guru di kelasnya dalam upaya meningkatkan mutu pembelajaran dengan metode, strategi atau model pembelajaran yang di sesuaikan dengan kondisi kelas dan karakteristik materi pelajaran.

Dengan demikian PTK dapat dilakukan dengan beberapa siklus yang saling berkaitan satu sama lain. Adapun menurut Iskandar (2015, hlm.4-5) yang menjelaskan karakterristik PTK, antara lain:

1) Kontekstual, skala kecil dan lokal yaitu mendefinisikan dan menyelidiki masalah dalam situasi tertentu.

2) Evaluasi dan refleksi bertujuan untuk membawa perubahan dan 
perbaikan praktik.

3) Partisipatif untuk menyelidikan kolaboratitif tim rekan, praktisi dan peneliti.

4) Perubahan dalam praktik didasarkan pada pengumpulan informasi atau data pendukung perubahan.

\section{Berdasarkan pendapat-} pendapat di atas, bahwa dilakukannya PTK adalah dalam rangka guru bersedia untuk mengintropeksi, merefleksi dan mengevaluasi dirinya sendiri sehingga kemampuannya sebagai seorang pengajar diharapkan cukup profesional untuk selanjutnya, diharapkan dari peningkatan kemampuan diri tersebut dapat berpengaruh terhadap peningkatan kualitas peserta didiknya, baik dalam aspek pemahaman, sikap dan keterampilan maupun aspek-aspek lainnya yang bermanfaat bagi peserta didik untuk menjadi dewasa.

\section{PEMBAHASAN}

\section{Rencana \\ Pelaksanaan \\ Pembelajaran (RPP)}

Rekapitulasi nilai peningkatan rencana pelaksanaan pembelajaran (RPP) siklus I, II dan III sebagai berikut :

Tabel 1 Rekapitulasi Nilai dan Persentase
Peningkatan Rencana Pelaksanan
Pembelajaran (RPP)
\begin{tabular}{|l|c|c|c|c|}
\hline No. & Siklus & Persentase & $\begin{array}{c}\text { Nilai } \\
\text { Akhir }\end{array}$ & Kriteria \\
\hline 1. & Siklus I & $50 \%$ & 2,00 & Cukup \\
\hline 2. & Siklus II & $70 \%$ & 2,80 & Baik \\
\hline 3. & Siklus III & $80 \%$ & 3,20 & Baik \\
\hline
\end{tabular}

\section{Rencana}

$$
\text { pelaksanaan }
$$

pembelajaran (RPP) mengalami peningkatan pada setiap sikusnya. Pada siklus I yang ditunjukan tabel 4.2 rencana pelaksanaan pembelajaran (RPP) memperoleh Persentase $50 \%$ lalu meningkat menjadi $70 \%$ di siklus II pada tabel 4.8 berdasarkan tabel 1 siklus III rencana pelaksanaan pembelajaran (RPP) mencapai hasil $80 \%$. Hal ini menunjang peningkatan dari setiap siklusnya.

\section{Pelaksanaan Pembelajaran}

Rekapitulasi nilai peningkatan pelaksanan pembelajaran siklus I, II dan III sebagai berikut :

Tabel 2 Rekapitulasi Nilai dan Persentase Peningkatan Pelaksanaan Pembelajaran

\begin{tabular}{|l|l|c|c|c|}
\hline No. & Siklus & $\begin{array}{c}\text { Persen } \\
\text { tase }\end{array}$ & $\begin{array}{c}\text { Nilai } \\
\text { Akhir }\end{array}$ & Kriteria \\
\hline 1. & Siklus I & $53 \%$ & 2,13 & Cukup \\
\hline 2. & Siklus II & $68 \%$ & 2,72 & Cukup \\
\hline 3. & Siklus III & $77 \%$ & 3,09 & Baik \\
\hline
\end{tabular}




\section{Pelaksanaan pembelajaran} mengalami peningkatan pada setiap sikusnya. Pada siklus I yang ditunjukan tabel 1 memperoleh Persentase $50 \%$ lalu meningkat menjadi $70 \%$ di siklus II, dan siklus III rencana pelaksanaan pembelajaran (RPP) mencapai hasil $80 \%$. Hal ini menunjang peningkatan dari setiap siklusnya.

\section{Penilaian Kognitif}

Rekapitulasi nilai peningkatan nilai rata-rata dan Persentase Pretest dan Posttest siklus I, II dan III sebagai berikut :

Tabel 3 Rekapitulasi Nilai Rata-Rata dan

\begin{tabular}{|l|l|c|c|c|}
\multicolumn{5}{|c|}{ Persentase Peningkatan Pretest } \\
\hline $\begin{array}{c}\text { N } \\
\text { o. }\end{array}$ & Siklus & $\begin{array}{c}\text { Pers } \\
\text { enta } \\
\text { se }\end{array}$ & $\begin{array}{c}\text { Rera } \\
\text { ta }\end{array}$ & $\begin{array}{c}\text { Kriteri } \\
\text { a }\end{array}$ \\
\hline 1. & Siklus I & $30 \%$ & 66 & Cukup \\
\hline 2. & Siklus II & $73 \%$ & 71 & Baik \\
\hline 3. & Siklus III & $86 \%$ & 73 & Baik \\
\hline
\end{tabular}

Pretest mengalami peningkatan pada setiap sikusnya. Pada siklus I yang ditunjukan tabel 4.4 memperoleh Persentase 30\% lalu meningkat menjadi $73 \%$ di siklus II pada tabel 4.10 berdasarkan tabel 4.16 siklus III rencana pelaksanaan pembelajaran (RPP) mencapai hasil $86 \%$. Hal ini menunjang peningkatan dari setiap siklusnya.

Tabel 4 Rekapitulasi Nilai Rata-Rata dan Persentase Peningkatan Posttest

\begin{tabular}{|l|l|c|c|c|}
\hline No. & Siklus & $\begin{array}{c}\text { Persen } \\
\text { tase }\end{array}$ & $\begin{array}{c}\text { Rata- } \\
\text { Rata }\end{array}$ & $\begin{array}{c}\text { Krite } \\
\text { ria }\end{array}$ \\
\hline 1. & Siklus I & $57 \%$ & 69 & $\begin{array}{c}\text { Cuku } \\
\mathrm{p}\end{array}$ \\
\hline 2. & Siklus II & $87 \%$ & 72 & Baik \\
\hline 3. & Siklus III & $93 \%$ & 74 & Baik \\
\hline \multicolumn{3}{|c}{ Posttest } & \multicolumn{3}{c|}{ mengalami }
\end{tabular}

peningkatan pada setiap sikusnya. Pada siklus I yang ditunjukan tabel 4.5 memperoleh Persentase 57\% lalu meningkat menjadi $86 \%$ di siklus II pada tabel 4 dan siklus III rencana pelaksanaan pembelajaran (RPP) mencapai hasil 93\%. Hal ini menunjang peningkatan dari setiap siklusnya

\section{Penilaian Afektif}

Rekapitulasi nilai peningkatan sikap santun dan peduli siklus I, II dan III sebagai berikut :

Tabel 5 Rekapitulasi Peningkatan Sikap Santun dan Sikap Peduli

\begin{tabular}{|l|l|c|c|c|}
\hline No. & Siklus & $\begin{array}{c}\text { Pers } \\
\text { en- } \\
\text { tase }\end{array}$ & $\begin{array}{c}\text { Rata- } \\
\text { Rata }\end{array}$ & Kriteria \\
\hline 1. & Siklus I & $33 \%$ & 61 & Kurang \\
\hline 2. & Siklus II & $53 \%$ & 63 & Kurang \\
\hline 3. & Siklus III & $93 \%$ & 74 & Baik \\
\hline \multicolumn{5}{|c}{ Penilaian afektif mengalami }
\end{tabular}

peningkatan pada setiap sikusnya.

Pada siklus I yang ditunjukan tabel 4.6 memperoleh Persentase 33\% lalu meningkat menjadi 53\% di siklus II pada tabel 4.12 berdasarkan tabel 4.18 siklus III rencana pelaksanaan 
pembelajaran (RPP) mencapai hasil 93\%. Hal ini menunjang peningkatan dari setiap siklusnya.

\section{Penilaian Psikomotor}

Rekapitulasi nilai peningkatan membuat peta pikiran siklus I, II dan III sebagai berikut :

Tabel 6 Rekapitulasi Peningkatan Membuat Peta Pikiran

\begin{tabular}{|l|l|c|c|c|}
\hline No. & Siklus & $\begin{array}{c}\text { Persen } \\
\text { tase }\end{array}$ & $\begin{array}{c}\text { Rata- } \\
\text { Rata }\end{array}$ & Kriteria \\
\hline 1. & Siklus I & $20 \%$ & 55 & Kurang \\
\hline 2. & Siklus II & $60 \%$ & 69 & Cukup \\
\hline 3. & Siklus III & $80 \%$ & 71 & Baik \\
\hline \multicolumn{4}{|c}{ Penilaian } & \multicolumn{3}{c}{ psikomotor }
\end{tabular}

mengalami peningkatan pada setiap sikusnya. Pada siklus I yang ditunjukan tabel 6 memperoleh Persentase $20 \%$ lalu meningkat menjadi $60 \%$ di siklus II, dan siklus III rencana pelaksanaan pembelajaran (RPP) mencapai hasil $80 \%$. Hal ini menunjang peningkatan dari setiap siklusnya.

\section{Lembar Wawancara}

\section{Berdasarkan beberapa} pertanyaan yang diajukan oleh peneliti kepada observer yaitu guru kelas IV D, menurut observer model Cooperative Learning tipe Mind Mapping membuat kegiatan pembelajaran menjadi lebih efektif pada subtema keberagaman dalam kebersamaan, karna dapat meningkatkan antusias siswa dalam kegiatan pembelajaran berkelompok dengan mengguanakn sistem point dan untuk kelompok yan dapat bekerja berkelompok dengan baik akan mendapatkan reward sehingga siswa terlihat aktif dalam kegiatan pembelajaran. Pertanyaan yang diajukan oleh peneliti dan jawaban yang diberikan oleh observer sebagai berikut :

Tabel 7 Lembar Wawancara Guru

\begin{tabular}{|c|c|c|}
\hline No. & Pertanyaan & $\begin{array}{c}\text { Ringkasan } \\
\text { Jawaban }\end{array}$ \\
\hline 1. & $\begin{array}{l}\text { Bagaimana } \\
\text { pendapat } \\
\text { menurut } \\
\text { Bapak/lbu } \\
\text { tentang } \\
\text { penggunaan } \\
\text { model } \\
\text { Cooperative } \\
\text { Learning tipe } \\
\text { Mind Mapping } \\
\text { dikelas IV D } \\
\text { dalam } \\
\text { subtema } \\
\text { kebersamaan } \\
\text { dalam } \\
\text { keberagaman? }\end{array}$ & $\begin{array}{l}\text { Menurut saya } \\
\text { ada kecocokan } \\
\text { antara } \\
\text { subtema } \\
\text { kebersamaan } \\
\text { dalam } \\
\text { keberagaman } \\
\text { dengan model } \\
\text { Cooperative } \\
\text { Learning tipe } \\
\text { Mind Mapping } \\
\text { karna pada } \\
\text { dasarnya anak } \\
\text { belajar secara } \\
\text { berkelompok } \\
\text { dan berdiskusi. }\end{array}$ \\
\hline 2. & $\begin{array}{l}\text { Bagaimana } \\
\text { menurut } \\
\text { Bapak/lbu } \\
\text { dengan respon } \\
\text { siswa setelah } \\
\text { diterapkannya } \\
\text { model } \\
\text { Cooperative } \\
\text { Learning tipe }\end{array}$ & $\begin{array}{l}\text { Respon baik } \\
\text { yang terlihat } \\
\text { oleh saya, } \\
\text { karna anak jadi } \\
\text { dapat belajar } \\
\text { bagaimana } \\
\text { cara } \\
\text { menghargai } \\
\text { pendapat }\end{array}$ \\
\hline
\end{tabular}




\begin{tabular}{|c|c|c|}
\hline No. & Pertanyaan & $\begin{array}{c}\text { Ringkasan } \\
\text { Jawaban }\end{array}$ \\
\hline & $\begin{array}{l}\text { Mind Mapping } \\
\text { dalam kelas? }\end{array}$ & $\begin{array}{l}\text { teman-teman } \\
\text { yang lain dan } \\
\text { mejadi lebih } \\
\text { aktif dalam } \\
\text { kegiatan } \\
\text { pembelajaran. }\end{array}$ \\
\hline 3. & $\begin{array}{l}\text { Apakah } \\
\text { dengan } \\
\text { penerapan } \\
\text { model } \\
\text { Cooperative } \\
\text { Learning tipe } \\
\text { Mind Mapping } \\
\text { pada subtema } \\
\text { kebersamaan } \\
\text { dalam } \\
\text { keberagaman } \\
\text { dapat } \\
\text { meningkatkan } \\
\text { hasil belajar? }\end{array}$ & $\begin{array}{l}\text { Siswa } \\
\text { merespon } \\
\text { setiap kegiatan } \\
\text { dengan baik } \\
\text { maka } \\
\text { pemahaman } \\
\text { tentang materi } \\
\text { pun meningkat } \\
\text { karna itu hasil } \\
\text { beajar pun bisa } \\
\text { meningkat. }\end{array}$ \\
\hline 4. & $\begin{array}{l}\text { Kendala apa } \\
\text { yang } \\
\text { Bapak/lbu } \\
\text { rasakan ketika } \\
\text { melakukan } \\
\text { kegiatan } \\
\text { pembelajaran } \\
\text { pada bisanya? }\end{array}$ & $\begin{array}{l}\text { Siswa kurang } \\
\text { merespon } \\
\text { dengan baik, } \\
\text { ada beberapa } \\
\text { siswa yang } \\
\text { tidak } \\
\text { mendengarkan } \\
\text { dan malah } \\
\text { mengobrol } \\
\text { dengan } \\
\text { temannya dan } \\
\text { pada kegiatan } \\
\text { diskusi siswa } \\
\text { cenderung } \\
\text { mengobrol. }\end{array}$ \\
\hline 5. & $\begin{array}{l}\text { Bagaimana } \\
\text { saran } \\
\text { Bapak/lbu } \\
\text { untuk kegiatan } \\
\text { pembelajaran } \\
\text { selanjutnya? }\end{array}$ & $\begin{array}{l}\text { Saya harap } \\
\text { pengguanaan } \\
\text { model } \\
\text { pembelajaran } \\
\text { dapat di } \\
\text { gunakan } \\
\text { dengan baik } \\
\text { dan dapat } \\
\text { menselaraskan } \\
\text { atara kegiatan } \\
\text { dengan model } \\
\text { pembelajaran }\end{array}$ \\
\hline
\end{tabular}

\begin{tabular}{|c|c|c|}
\hline No. & Pertanyaan & $\begin{array}{c}\text { Ringkasan } \\
\text { Jawaban }\end{array}$ \\
\hline & & $\begin{array}{l}\text { yang akan } \\
\text { digunakan } \\
\text { sehingga hasil } \\
\text { belajar siswa } \\
\text { dapat } \\
\text { meningkat } \\
\text { dengan baik. }\end{array}$ \\
\hline
\end{tabular}

\section{E. KESIMPULAN}

Berdasarkan hasil penelitian yang di peroleh oleh peneliti selama melakukan Penelitian Tindakan Kelas dengan menggunakan model Cooperative Learning tipe Mind Mapping di kelas IV D SDN Komplek Karang Taruna Sari dapat di deskripsikan sebagai berikut:

1. Pada kegiatan perencanaan pembelajaran dari setiap siklus, terutama dalam pembuatan Rencana Pelaksanaan Pembelajaran (RPP) sesuai dengan model yang di gunakan yaitu Cooperative Learning tipe Mind Mapping dan materi yang dipelajari yaitu tema Indahnya Kebersamaan dan subtema Kebersamaan dalam Keberagaman, pembelajaran 1, 2, 3, 4, 5 dan 6 terbukti dapat meningkatkan hasil belajar siswa. Hal ini dapat terlihat dari penilaian rencana pelaksanaan 
pembelajaran menggunakan

rubik RPP (terlampir) pada

sisklus III mecapai nilai 3,20 dengan Persentase $80 \%$ (katergori baik). Dengan demikian rencana pelaksanaan pembelajaran yang telah dibuat dinyatakan baik dan hasilnya memuaskan. Hal ini tidak terlepas dari dukungan penuh guru kelas IV D SDN Komplek Karang Taruna Sari sehingga penelitian ini dapat berjalan dengan baik.

2. Pada saat pelaksanaan pembelajaran menggunakan model Cooperative Learning tipe Mind Mapping, siswa terlihat antusias mengikuti kegiatan pembelajaran yang di lakukan sehingga pemahaman konsep siswa dan hasil belajar siswa dapat meningkat hal ini dapat terlihat dari penilaian pelaksanaan pembelajaran pada siklus III mencapai nilai 3,09 dengan Persentase 77\%. Dengan demikian pelaksanaan pembelajaran yang telah dilaksanakan oleh guru (peneliti) dinyatakan

baik

dan memuaskan.

3. Adanya perubahan sikap santun dan peduli siswa yang terlihat setelah dilakukannya model pembelajaran Cooperative Learning tipe Mind Mapping terlihat pada siklus III dalam penilaian afektif mencapai nilai rata-rata siswa 74 (kategori baik) dengan Persentase 93\%. Dengan demikian sikap siswa dinyatakan berhasil mencapai tujuan pembelajaran.

4. Setelah diterapkannya model Cooperative Learning tipe Mind Mapping, hasil belajar siswa meningkat. Hal tersebut terlihat dari hasil nilai Pretest dan Posttest siswa pada siklus III, pada Pretest mencapai nilai rata-rata siswa 72 dengan Persentase $86 \%$ dan pada psttest mencapai nilai rata-rata siswa 74 dengan Persentase 93\%. Dengan demikian hasil belajar siswa dinyatakan berhasil karna telah melebihi KKM yang di tentukan.

DAFTAR PUSTAKA 
Depdiknas.(2003) Undang-Undang Dasar Republik Indonesia No.20 Tahun 2003 Tentang Sistem Pendidikan Nasional.

Kemendikbud.2016) Permendikbud Republik Indonesia No.22 Tahun 2016 tentang Rencana Pelaksanaan Pembelajaran (RPP).

.(2016) Permendik-

bud Republik Indonesia No.23 Tahun 2016 tentang Penilaian Pelaksanaan Pembelajaran.

Ade, M. (2010). Membangun Relasi Sosial Melalui Komunikasi Empatik. Jurnal Dakwah dan Komunikasi. 4(1). 14-31. http://scholar.googleusercontent .com/scholar?q=cache:SnYH8E oj1TgJ:scholar.google.com/+me mbangun+relasi+sosial+melalui +komunikasi+empatik\&hl=en\&a s_sdt=0,5.

(Diakses tanggal 10 Mei 2017).

Afid Burhanuddin (2013) Instrumen Penelitian.Diakses dari halaman web tanggal 3 juni 2017 dari: https://afidburhanuddin.wordpre ss.com/2013/05/21/pengumpula n-data-dan-instrumenpenelitian-3/

Agustina Zubair. (2006, September). Komunikasi. Diakses dari laman web https://meiliemma.wordpress.co m/2006/09/27/kuliah-23pengantar-ilmu-komunikasi-msagustina-zubair/.
Anugrah Dino. (2014, April). Komunikasi. Diakses dari laman web

http://www.anugerahdino.com/2 014/04/faktor-faktor-

penghambat-komunikasi.html

Aqib, Zainal. (2011). Penelitian Tindakan Kelas. Bandung: Yrama Widya.

Anggari St,dkk. (2015). Buku Guru Indahnya Kebersamaan. Jakarta : Pusat Kurikulum dan Pembukuan Balitbang Kemebdikbud.

Anggari St,dkk. (2015). Buku Siswa Indahnya Kebersamaan. Jakarta : Pusat Kurikulum dan Pembukuan Balitbang Kemebdikbud.

Arikunto, S. (2012). Penelitian Tindakan Kelas. Jakarta: Bumi Aksara

Anita Lie. (2008). Cooperative Learning. Jakarta: PT Grasindo.

Dr. Nunuk Suryani, \& Dr.Leo Agung S, M.Pd (2012). Strategi Belajar MengajarYogyakarta: ombak

Dr. Sauri S .(2013). Pengembangan Strategi Pendidikan Berbahasa Santun di Sekolah. Sofyan Sauri.1(22).4553.

scholar.googleusercontent.com/ scholar?q=cache:80OxVzE6Sd QJ:scholar.google.com/+sikap+ santun\&hl=en\&as_sdt=0,5. 
(Diakses tanggal 9 Mei 2017).

Dr. Sauri S.(2013). Membangun Profesionalisme Guru Berbasis Nilai Bahasa

Santun

Bagi Pembinaan Kepribadian Bangsa yang Bijak. Sofyan Sauri.1(22).45-53.

scholar.googleusercontent.com/ scholar?q=cache:DAwuGw6L3_ 4J:scholar.google.com/+sikap+s antun\&hl=en\&as_sdt $=0,5$

(Diakses tanggal 10 Mei 2017).

Fatoni. (2016, April). Sintak-Sintak Pembelajaran Cooperative Learning. Diakses dari alamat web

https://fatonipgsd071644221.wo rdpress.com/2010/01/12/sintaks -tahapan-model-modelpembelajaran/.

FKIP Universitas Pasundan. (2017). Panduan Praktek Pengalaman Lapangan. Universitas Pasundan Bandung.

FKIP Universitas Pasundan. (2017). Panduan Penulisan Karya Tulis IImiah (KTI). Universitas Pasundan Bandung.

Fransisca, T. (2008). Meningkatkan Pemahaman dan Retensi Siswa Melalui Pembelajaran Berbasis Teknologi Multimedia Interaktif. Jurnal Pendidikan Teknologi Informasi dan Komunikasi. 1(2). 19-26.

http://scholar.googleusercontent .com/scholar?q=cache:MUDtQ8 92xt4J:scholar.google.com/+jurn al+pendidikan+teknologi+inform asi+dan+komunikasi\&hl=en\&as _sdt=0,5.

(Diakses tanggal 8 Mei 2017).

Heriawan, A, dkk. (2012). Metodologi Pembelajaran. Banten: PL3G.

Huda, M. (2014). Cooperative Learning. Yogyakarta: Pustaka Pelajar.

Huda, M. (2014). Model-model Pengajaran dan Pembelajaran. Yogyakarta: Pustaka Pelajar.

Isjoni, (2011). Cooperative Learning. Bandung: Alfabeta.

Jamil, S. (2016). Strategi Pembelajaran. Yogyakarta: Arruzz Media.

Jufri, W.(2017). Belajar dan Pembelajaran SAINS. Bandung: Pustaka Reka Cipta.

Kosasih, (2014). Strategi Belelajar dan Pembelajaran Implementasi Kurikulum 2013. Bandung: Yrama Widya.

Kusnawan, D. (2013). Analisis Belajar Program Perbaikan Pada Program Pengayaan. Depok: Luxima.

P. S, M. (2012). Pengembangan Model Pembelajaran Fisika Berbasis Problem Solving Untuk Meningkatkan Kemampuan Metakognisi dan Pemahaman Konsep Mahasiswa. Jurnal 
Pendidikan Fisika Indonesia.

8(1). 152-160.

https://journal.unnes.ac.id/nju/in

dex.php/JPFI/article/view/2155.

(Diakses tanggal 8 Mei 2017).

Rini Andriani. (2017, Mei). Model Pembelajaran Mind Mapping. Diakses dari web http://www.duniapembelajaran.c om/2015/02/prosedur-modelpembelajaran-mindmapping.html.

Sherly Rachma Sanie. (2012, Desember). Faktor yang Mempengaruhi Belajar. Diakses dari laman web http://sherlyrachmasanie.blogsp ot.co.id/2012/12/faktorfaktoryang-mempengaruhibelajar.html

Sugiyono.

(2011). Metode Penelitian Pendidikan Pendekatan Kualitatif, Kuantitatif dan $R \& D$. Bandung: Alfabeta

Suyadi,M.Pd.I, (2012). Strategi Pembelajaran Pendidikan Karakter. Jakarta: Rosda.

Suyadi,M.Pd.I, (2012). Pembelajaran Pendidikan Karakter. Jakarta: Rosda.

Slavin, R. (2015). Cooperative Learning. Bandung: Penerbit Nusa Media

Sudjana, N. (2016). Penilaian Hasil Proses Belajar Mengajar.
Bandung: PT Remaja
Rosdakarya

Trianto,M.Pd, (2009), Mendesain Model Pembelajaran inovatifprogresif.Jakarta: Kencana

Trianto,M.Pd, (2009),Model-Model Pembelajaran Inovatif Berorientasi

Konstruktivistik.Jakarta: Prestasi Pustaka.

Wahyu, I, N. (2013). Pengaruh Implementasi Pendekatan Proses Berbasis Lingkungan Siswa Kelas V MIN Banyubiru Negara. E-journal Program Pascasarjana Universitas Pendidikan Ganesha. 3(1). 1-10. http://119.252.161.254/ejournal/index.php/jurnal_pendas /article/view/601.

(Diakses tanggal 10 Mei 2017).

Wardani. (2014). Hakikat Penelitian Tindakan Kelas. Diakses dari halaman web tanggal 19 mei 2017 dari:

http://repository.ut.ac.id/4153/1/IDI K4008-M1.pdf

Wibawa, S. (2014). Penelitian Tindakan Kelas. Diakses dari halaman web tanggal 20 mei 2017 dari:

http://staff.uny.ac.id/sites/default/fil es/pengabdian/dr-sutrisnawibawa-mpd/penelitiantindakan-kelas-plpg2012.pdf 